\title{
Non-crop habitats modulate alpha and beta diversity of flower flies (Diptera, Syrphidae) in Brazilian agricultural landscapes
}

\author{
Hugo Reis Medeiros ${ }^{1,2} \cdot$ Adriano Thibes Hoshino $^{2} \cdot$ Milton Cezar Ribeiro $^{1}$. \\ Mírian Nunes Morales ${ }^{3} \cdot$ Felipe Martello $^{4}$ - Osvaldo Coelho Pereira Neto ${ }^{5}$. \\ Daniel Wisbech Carstensen $^{6}$ - Ayres de Oliveira Menezes Junior ${ }^{2}$
}

Received: 2 July 2017 / Revised: 9 December 2017 / Accepted: 15 December 2017 /

Published online: 20 December 2017

(C) Springer Science+Business Media B.V., part of Springer Nature 2017

\begin{abstract}
Non-crop habitats play a key role in maintaining functional diversity and ecosystem services in farmland. However, the interplay between beneficial insects and landscape variables has rarely been investigated in Neotropical agroecosystems. We used flower flies as a model group to investigate the effects of landscape attributes on beneficial insects in agroecosystems across a gradient of landscape complexity. We specifically ask: (i) Do the abundance and species richness of flower flies in cereal crops increase with increasing landscape complexity? (ii) Do the effects of landscape variables on local flower fly communities differ between spatial scales? (iii) How do landscape complexity and local factors (crop size, altitude and insecticide applications) affect beta diversity? We sampled flower flies in 54 edges within 18 wheat crops in Paraná State, southern Brazil. The percentage of non-crop habitats, landscape diversity and edge density were the explanatory variables,
\end{abstract}

Communicated by P. Ponel.

Electronic supplementary material The online version of this article (https://doi.org/10.1007/ s10531-017-1495-5) contains supplementary material, which is available to authorized users.

Hugo Reis Medeiros

hugo.medeiros.r@gmail.com

1 Bioscience Institute, Department of Ecology, Spatial Ecology and Conservation Lab (LEEC), UNESP - Universidade Estadual Paulista, Rio Claro, São Paulo 13506-900, Brazil

2 Graduate Program in Agronomy, UEL - Universidade Estadual de Londrina, P.O. Box 6001, Londrina, Paraná 86057-970, Brazil

3 Graduate Program in Entomology, UFLA - Universidade Federal de Lavras, P.O. Box 3037, Lavras, Minas Gerais 37200-000, Brazil

4 Department of Environmental Sciences, UFSCAR - Universidade Federal de São Carlos, P.O. Box 676, São Carlos, São Paulo 13565-905, Brazil

5 Department of Geosciences, UEL - Universidade Estadual de Londrina, P.O. Box 6001, Londrina, Paraná 86057-970, Brazil

6 Center for Macroecology, Evolution and Climate, Natural History Museum of Denmark, University of Copenhagen, Universitetsparken 15, 2100 Copenhagen, Denmark 
which were calculated at multiple spatial scales for each landscape. We collected 8340 flower flies, distributed in 12 genera and 52 species. Species richness was positively associated with the percentage of non-crop habitats, but total abundance presented non-clear pattern. However, abundance without the dominant species was also positively associated with the percentage non-crop habitats. Similarly, beta diversity was related to non-crop habitats, suggesting that the reduction in non-crop habitats implies in species loss. We have provided the first insights into the importance of non-crop habitats on the conservation of beneficial insects within Neotropical farmlands. To guarantee high levels of biodiversity within agroecosystems we need to promote the conservation and restoration of non-crop habitats in the surrounding landscapes.

Keywords Agroecosystems $\cdot$ Beneficial insects $\cdot$ Biodiversity conservation $\cdot$ Natural habitats

\section{Introduction}

The processes of habitat loss and fragmentation are the major threats to biodiversity (Fahrig 2003, 2017). The main driving force behind these processes is agricultural intensification, which negatively affects biodiversity from local to landscape scales (SteffanDewenter et al. 2002; Thies et al. 2003; Tscharntke et al. 2005; Meehan et al. 2011). At the local scale, the overuse of pesticides increases both mortality rates and sublethal effects in organisms foraging in agricultural fields (Geiger et al. 2010; Stapel et al. 2000). At the landscape scale, the expansion of crop area strongly reduces the amount and diversity of natural and semi-natural habitats, which play a key role in maintaining high levels of animal diversity in farmlands (Aviron et al. 2005; Billeter et al. 2008; Fahrig et al. 2011).

Natural and semi-natural habitats such as forests, grasslands, hedgerows and abandoned pastures (hereafter, non-crop habitats) are relatively stable and provide refuge for biodiversity, particularly during disturbance periods in crops such as pesticide applications, tillage and harvesting operations (Altieri 1999; Fahrig et al. 2011; Tscharntke et al. 2012). Most species rely on non-crop habitats for the constant provision of vital resources: food, shelter, overwintering sites and mating sites (Altieri 1999; Landis et al. 2000; Bianchi et al. 2006; Tscharntke et al. 2007, 2012). Furthermore, high levels of habitat diversity and edge density in the surrounding landscape can provide spatiotemporal refugia for biodiversity via landscape complementation and supplementation (see Tscharntke et al. 2012; Fahrig 2017). This can be particularly important for crop-associated species with periodical movement between crop and non-crop habitats. Indeed, studies have indicated that complexstructured landscapes, with high habitat diversity and high percentage of non-crop habitats, can support more diverse communities than simpler and agriculture-dominated landscapes (Yachi and Loreau 1999; Loreau et al. 2003; Tscharntke et al. 2007, 2012).

Landscape structure influences biodiversity not just changing richness and abundance, but also how species composition varies between sites-beta diversity (Hendrickx et al. 2007; Zellweger et al. 2017). Total beta diversity can be decomposed in two components: (a) the turnover component that represents the changes of species between communities, and (b) the nested component that is the loss of species between communities (Baselga 2010). Although the turnover is the major contributor to total beta diversity ( $\mathrm{Si}$ et al. 2015; Zellweger et al. 2017), the nested component rises as an important factor in scenarios of habitat loss and fragmentation such as crop-dominated landscapes (Buhk et al. 2017). 
Understanding changes in community composition can elucidate the drivers that influence community assembly, ecosystem stability and biotic homogenization (Catano et al. 2017).

The effects of landscape complexity on biodiversity are well known in temperate regions; however, it remains unexplored in agricultural landscapes of the Neotropical region, wherein only a few works can be found for Chile (Grez and Prado 2000; Zaviezo et al. 2006), Argentina (Rossetti et al. 2014; González et al. 2015, 2016a, b, 2017) and Brazil (Medeiros et al. 2016). We used flower flies (Syrphidae, Diptera) as a model group to elucidate how landscape complexity modulates the structure of local communities in Brazilian agricultural landscapes. Numerous adult flower flies may play an important role as pollinators in both managed and natural ecosystems (Fontaine et al. 2006; Jauker and Wolters 2008; Jauker et al. 2009; Lucas et al. 2017). Furthermore, flower fly larvae are good bioindicators because they have a great variety of functional groups with specific habitat and food requirements (Gilbert et al. 1994; Sommaggio 1999; Burgio and Sommaggio 2007). These insects can be found in crop and non-crop habitats and both species richness and community composition are affected by human impacts at local and landscape scales (Rotheray and Gilbert 2011; Schweiger et al. 2007; Meyer et al. 2009; Haenke et al. 2014).

However, the interplay between beneficial insects and landscape variables rarely has been investigated in Neotropical agroecosystems. In this study we aim answer the following questions: (i) Do the abundance and species richness of flower flies in cereal crops increase with increasing landscape complexity? (ii) Do the effects of landscape variables on local flower fly communities differ between spatial scales? (iii) How do landscape complexity and local factors affect beta diversity? We represented landscape complexity by the percentage of non-crop habitats, habitat diversity and edge density. We also used crop size, altitude and insecticide applications as explanatory variables related to local factors.

We hypothesize that local communities are more affected by the percentage of non-crop habitats than by the other explanatory variables, as larvae of most species depend on the presence of micro-habitats that are found only in non-crop habitats. We also expect similar positive effects of non-crop habitats on flower flies at all spatial scales, which would suggest that this insect group presents high dispersal capacity and depends on non-crop habitats at landscape scale to persist in farmland. Finally, comparing community composition between landscapes, we expect to find high values of nested beta diversity between pairs with high and low percentages of non-crop habitats, exposing the species loss in highly fragmented landscapes. This study provides the first insights on the responses of flower flies to landscape context in the Neotropical region. We highlight that agri-environment schemes designed to preserve biodiversity and ecosystem services in farmland must promote conservation and restoration of non-crop habitats at landscape scale.

\section{Materials and methods}

\section{Study sites}

The study was carried out in 54 edges distributed among 18 conventionally managed wheat crops (three edges per crop) that are situated along a gradient of landscape complexity in the Paraná State, southern Brazil (Fig. 1). Because of logistic conditions, nine sites were sampled in 2012 and nine in 2013. The study region presents a humid subtropical climate (Köppen climate classification Cfa) with hot summers and infrequent frosts; average annual 


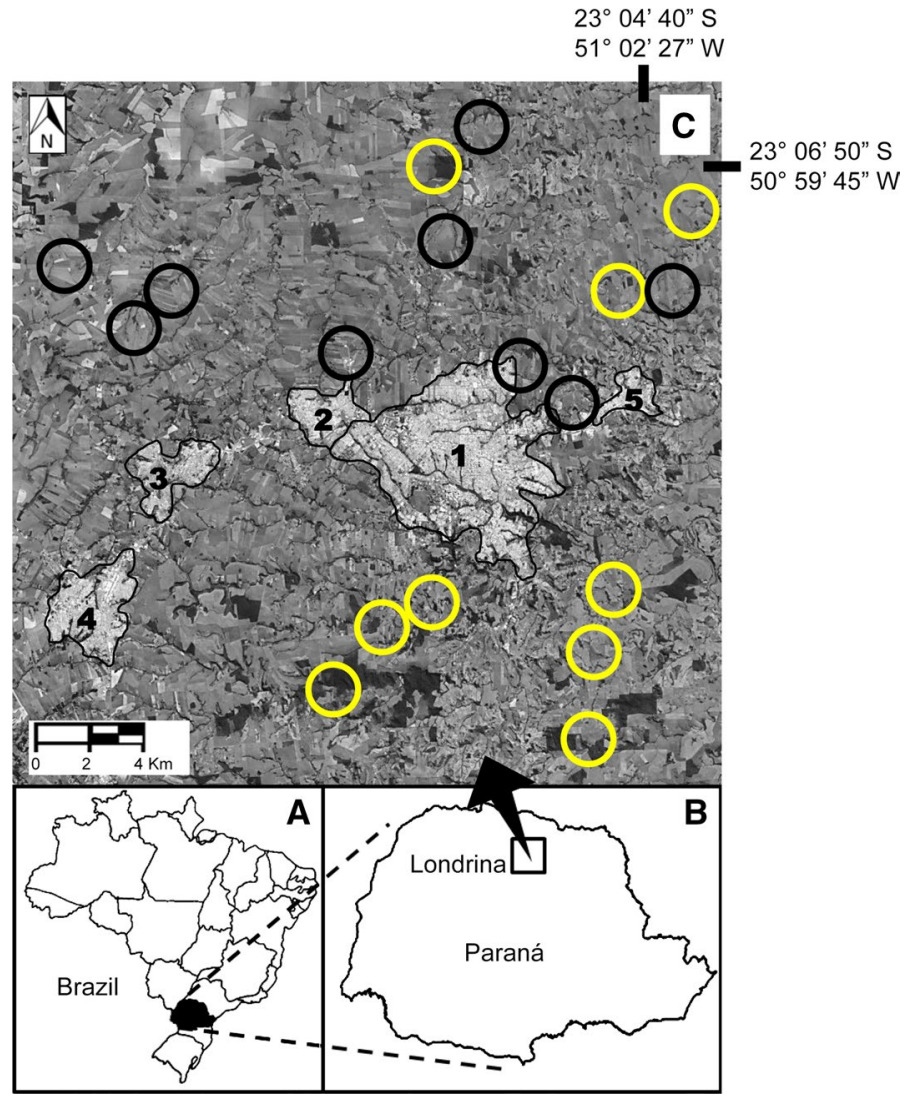

Fig. 1 Location of Paraná state in Brazil (a), Location of study region in northern Paraná State (b) and Location of the 18 landscape sectors in the metropolitan region of Londrina city (c). Source Metropoli$\tan$ region of Londrina city $23^{\circ} 55^{\prime} 46^{\prime \prime S}$ and $51^{\circ} 19^{\prime} 11^{\prime \prime} \mathrm{W}$. Google Earth. September 04, 2013. The numbers from 1 to 5 represent the urban areas of the cities of Londrina (1), Cambé (2), Rolândia (3), Arapongas (4) and Ibiporã (5). Yellow circles represent the 2-km landscape sectors sampled in 2012, while black circles indicate the landscapes sampled in 2013. (Color figure online)

rainfall of $1600 \mathrm{~mm}$, which is concentrated in the summer months; average annual temperature of $21{ }^{\circ} \mathrm{C}$ (IAPAR 2000). Soils at all sites have the same parent material (basalt) and consist of reddish clay (Rhodic Ferralsol; FAO 1988). In the present study, non-crop habitats encompass fragments of Seasonal Semidecidous Forest and abandoned pastures. Nowadays, this forest type is highly fragmented and covers only $7 \%$ of its original area (Ribeiro et al. 2009). Abandoned pastures are anthropic grasslands where exotic grasses are very common, supporting high diversity and density of weeds (Medeiros et al. 2016). The agricultural matrix is composed of arable crops under no-till farming system, where soybean is cultivated in the summer, wheat in the winter, and corn in both seasons.

\section{Sampling of flower flies}

Flower flies (Syrphidae, Diptera) were sampled using three Malaise traps (model Townes 1972) per wheat crop. Within each crop, the traps were placed at $25 \mathrm{~m}$ from the edges (one 
trap per edge), with a minimal distance of $300 \mathrm{~m}$ between traps. Traps were oriented northward and remained open during five consecutive weeks (from 23 April to 29 May 2012 and from 11 May to 16 June 2013). The difference in sampling dates between years was related to irregular rainfall in 2013 that delayed the wheat sowing. The captured insects were preserved in $70 \%$ ethanol for posterior identification. Flower flies were identified to the lowest taxonomic level possible using identification keys available in Thompson (1999), Thompson et al. (2000), Borges and Pamplona (2003), Borges and Couri (2009), Mengual et al. (2009), Mengual (2011), Miranda et al. (2014) and Miranda (2017). The taxa with no available identification keys were identified by M.N.Morales and by comparison with the material deposited at the Coleção Entomológica Padre Jesus Santiago Moure, Departamento de Zoologia da Universidade Federal do Paraná, Curitiba, Paraná, Brazil (DZUP).

To minimize the effects of insecticide applications, we captured flower flies during the initial phenological stages of wheat, from seedling emergence to tiller formation, when insecticides are usually not sprayed. Indeed, only two out 18 sampled crops had insecticide applications (two applications per crop); in both cases, Lepidoptera-specific physiological products were used.

\section{Flower fly diversity}

\section{Alpha diversity}

We estimated the species richness $(\mathrm{S})$ and total abundance $(\mathrm{N})$ of flower flies for each edge/ landscape, where $\mathrm{S}$ and $\mathrm{N}$ are the cumulative number of species and specimens recorded per crop, respectively. We used the rank/abundance plot (Whittaker 1965) to identify dominant species. This rank use quantitative data (log transformed species abundances +1$)$ to plot species in sequence from most to least abundant (Magurran 2004).

\section{Beta diversity}

We estimated total beta diversity as Sorensen's dissimilarity index ( $\beta$ sor) and decomposed it into two components: Turnover beta diversity, estimated with the Simpson dissimilarity index ( $\beta$ sim), and Nested beta diversity ( $\beta$ nes), which is the difference between $\beta$ sor and $\beta$ sim. The $\beta$ sim and $\beta$ nes refer to species replacement and the loss of species between sites, respectively, and reveal the processes involved in community assembly (Baselga 2010). Total beta diversity and its components were calculated using the presence-absence community matrix as input in the function beta.pair from the betapart package (Baselga and Orme 2012) in R software version 3.3.2.

\section{Explanatory variables}

Land use maps were built using Landsat/TM 5 (30 m resolution) satellite images projected in UTM SAD 1969 at 1/50,000 spatial scale. Extensive ground verification was used to achieve high accuracy of our maps. The satellite images were acquired between 2010 and 2012. Studies conducted in temperate regions found that flower flies respond to landscape context within $0.5-2 \mathrm{~km}$ range (Thies et al. 2003; Kleijn and Van Langevelde 2006; Gardiner et al. 2009; Meyer et al. 2009). Thus, we used these ranges as reference for computing our landscape metrics. We measured the percentage of noncrop habitat, Shannon landscape diversity index (landscape diversity) and Edge Density 
index at four spatial scales around the centre of the sampled crops $(0.5,1,1.5$ and $2 \mathrm{~km}$ radius). All this information was generated using the software ArcGIS 10.1 (ESRI, 2005).

Landscape diversity is the SHDI metric which is available in Fragstats (McGarigal 2015). Edge density represents the sum of the lengths (m) of all edge segments in the landscape, divided by the total landscape area $\left(\mathrm{m}^{2}\right)$. Edge density values are multiplied by 10,000 to convert to hectares (McGarigal 2015). We used the variables percentage of noncrop habitats and landscape diversity to represent landscape composition and the variable edge density as a metric of landscape configuration (Holzschuh et al. 2010). However, the variables landscape diversity and edge density were highly correlated (Spearman correlations $r>0.70 ; p<0.01)$ at all spatial scales. Therefore, to avoid multicollinearity and keep representing both landscape composition and configuration, we excluded landscape diversity from de analyses. In addition, we used crop size (ha), altitude (m.a.s.l) and pesticide usage as explanatory variables related to local factors. The variables percentage of noncrop habitats and altitude were log-transformed to allow linear regression analysis.

The 18 non-overlapping landscape buffers with $2-\mathrm{km}$ radii around the study sites varied in the percentage of non-crop habitats (from 7.4 to $74.4 \%$ ) and edge density (from 178 to $387 \mathrm{~m} / \mathrm{ha}$ ). Crop size ranged from 10.2 to 77.8 ha and distance between the sampled crops varied from 4.4 to $45.9 \mathrm{~km}$. Altitude varied from 380 to 690 m.a.s.l.

\section{Statistical analyses}

\section{Alpha diversity}

We used generalized linear mixed models (GLMMs) to estimate the relative contribution of the explanatory variables on the following response variables: species richness and abundance of flower flies. Considering that dominant species can affect total abundance responses we also analyzed total abundance without dominant species as a response variable. Abundance and species richness were fitted with Gaussian and Poisson error structure, respectively (Martensen et al. 2012). The analyses were made at multiple spatial scales.

For each dependent variable and spatial scale, we analyzed five competing models and a null model which represents the absence of an effect: (a) y percentage of noncrop habitats; (b) y edge density; (c) y altitude; (d) y $\sim$ crop size; and (e) y $\sim$ pesticide application. The variable year was included in the GLMM models as a random effect, in order to take in account a possible nested influence of the sampling years. The best models were identified using the Akaike Information Criterion (AIC; Burnham and Anderson 1998) with the small sample correction (AICc; Hurvich and Tsai 1989). We also used the AICc weight (wAICc) and AICc delta ( $\triangle \mathrm{AICc}$ ) to rank the models from the best to worst. The wAICc represents the weight of evidence in favor of a model given a list of competing models (Burnham and Anderson 2002). The $\triangle$ AICc is the difference between the AICc of a considered model and the best model, i.e. the model with lowest AICc value (Martensen et al. 2008). The models that presented $\mathrm{p}$ values $<0.05$ (model fit), wAICc $\geq 0.1$ and $\Delta \mathrm{AICc} \leq 2$ were considered as equally plausible to explain the dependent variables. All analyses were performed in $\mathrm{R}$ version 3.0.2 using the glmer function of the lme4 package (Bates et al. 2015) for species richness, the lme function of the nlme package (Pinheiro et al. 2017) for abundance and the AICctab function of the bbmle package (Bolker 2010) for model selection. 


\section{Beta diversity}

To test the effect of explanatory variables and spatial scales on total beta diversity and its components, we conducted a Redundancy Analysis (RDA) with 9999 permutations (Anderson 2001). RDA analysis is a multiple regression used to model multivariate response data (Legendre and Legendre 2012). We also used permuted test statistics to estimate relative contribution of each explanatory variable to explain beta diversity patterns. Additionally, we considered the coefficient of determination $\left(\mathrm{R}^{2}\right)$ of explanatory variables with significant value $(\mathrm{p}<0.05)$ as the relative contribution. For such analysis we used the function adonis of the vegan package (Oksanen et al. 2007).

Moreover, we calculated the proportion of contribution of each beta diversity component to total beta diversity by dividing each component by total beta diversity (Sorensen index). To evaluate the influence of landscape structure on beta diversity we calculated the difference of non-crop habitats for each paired landscape, and the respective beta diversity indices (nested and turnover). A model fit between landscape dissimilarity and beta diversity was generated throughout linear regression where the $\mathrm{R}^{2}$ and $\mathrm{p}$ values are informed.

\section{Results}

We collected a total of 8340 flower flies, distributed in 12 genera and 52 species (Supplementary Material 1). The abundance of flower flies ranged from 85 to 1005 specimens per crop and species richness varied from 8 to 48 species on the 18 wheat crops (Fig. 2). Using the rank/abundance plot three species were classified as dominant: Allograpta exotica (Wiedemann) $(\mathrm{n}=4313 ; 52 \%$ of all specimens), Pseudodoros clavatus (Fabricius) $(\mathrm{n}=1376 ; 16 \%)$ and Toxomerus politus (Say) $(\mathrm{n}=1115 ; 13 \%)$.

\section{Species richness and abundance}

Species richness was best explained by the percentage of non-crop habitats at all spatial scales from 0.5 to $2 \mathrm{~km}$ (wAICc values > 0.864; Table 1; Fig. 3). In contrast, none of the models explained total abundance. However, total abundance without the dominant species $(A$. exotica; $P$. clavatus and $T$. politus) was positively correlated with non-crop habitats also at all spatial scales (wAICc > 0.644; Table 1; Fig. 3).

\section{Beta diversity dissimilarity}

The decomposition of beta diversity showed that in average beta diversity (Sorensen index) was composed almost equally by turnover (mean $=56.22 \%, \mathrm{SD}=33.75$ ) and nested (mean $=43.77, \mathrm{SD}=33.75)$ components (Fig. 5). Total beta diversity and its nested component were explained only by the percentage of non-crop habitats at multiple spatial scales (Table 2; Fig. 4), while the turnover component was not explained by any of the explanatory variables. 


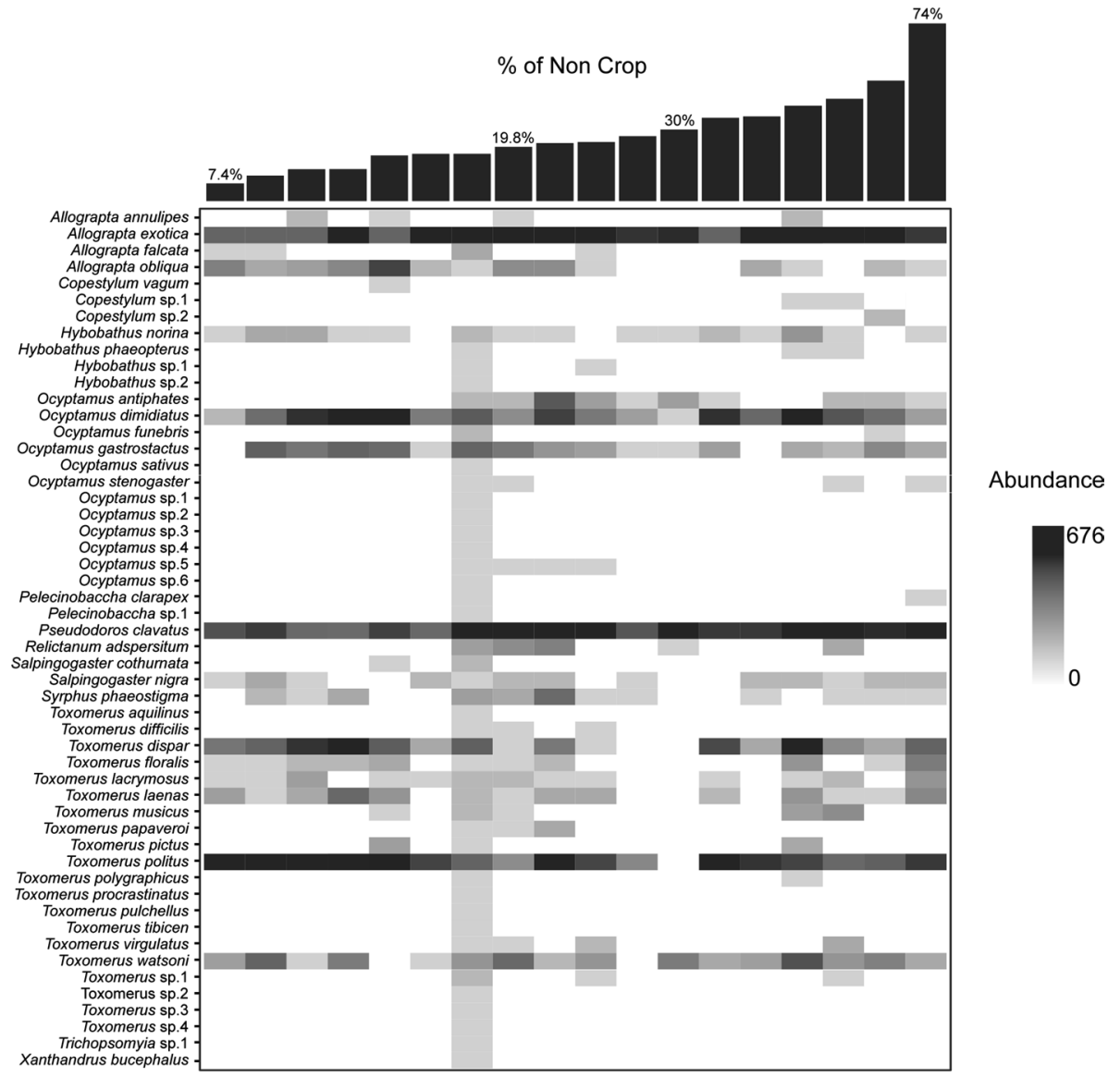

Fig. 2 Abundance of different flower fly species across the gradient of percentage of non-crop habitats. Abundance was log-transformed to allow the visualization of species with few individuals, but values on the scale are in numbers of individuals

\section{Discussion}

\section{Non-crop influences on species richness and abundance}

Local flower fly communities were modulated by the amount of non-crop habitats in the surrounding landscape, which confirm our hypothesis. Species richness increased with increasing percentage of non-crop habitats, and this was irrespective to spatial scales. Total beta diversity and its nested component were also affected by this variable, whereas its turnover component and total abundance were not explained by any of the explanatory variables. Such absence of effect on total abundance was influenced by the three dominant species in most of the landscapes: A. exotica, P. clavatus and T. politus. In fact, abundance without the dominant species was positively associated with non-crop habitats, which occurred independently of spatial scales used. Non-crop habitats are relatively stable and provide a variety of resources, such as prey and hosts, shelter, pollen and nectar for different arthropod functional groups (Altieri 1999; Landis et al. 2000; Tscharntke et al. 2007; 
Table 1 The best models to explain the species richness and abundance of flower flies in 18 agricultural landscapes in Paraná State, southern Brazil

\begin{tabular}{llll}
\hline Dependent variable & Spatial scales $(\mathrm{km})$ & Best models & wAICc \\
\hline Species richness & 2 & $\sim$ Non-crop habitats*** $(+)$ & 0.999 \\
& 1.5 & $\sim$ Non-crop habitats*** $(+)$ & 0.982 \\
& 1 & $\sim$ Non-crop habitats*** $(+)$ & 0.864 \\
Abundance without dominant & 2 & $\sim$ Non-crop habitats*** $(+)$ & 0.880 \\
species & 1.5 & $\sim$ Non-crop habitats** $(+)$ & 0.952 \\
& 1 & $\sim$ Non-crop habitats** $(+)$ & 0.937 \\
& 0.5 & $\sim$ Non-crop habitats* $(+)$ & 0.781 \\
& $\sim$ Non-crop habitats* $(+)$ & 0.644 \\
\hline
\end{tabular}

AICc Akaike Information Criterion with the small sample correction; and $w A I C c$ evidence weight of the model. Asterisks indicate the level of significance of the models (model fit). The symbols - and + within parenthesis indicate the direction of correlation between flower flies and the percentage non-crop habitats at four spatial scales that are represented in kilometers

$* \mathrm{p}<0.05 ; * * \mathrm{p}<0.01 ; * * * \mathrm{p}<0.001$

Larrivée et al. 2008), including flower flies (Kleijn and Van Langevelde 2006; Burgio and Sommaggio 2007; Schweiger et al. 2007; Meyer et al. 2009; Ricarte et al. 2011).

Recent studies have indicated that it is important to consider both adult and larval ecological requirements when assessing flower fly communities by sampling adults (Meyer et al. 2009; Mueller and Dauber 2016; Lucas et al. 2017). From this consideration arises the twofold importance of non-crop habitats for flower flies. First, these habitats support a wide diversity of plants and provide pollen and nectar for adult flies (Burgio and Sommaggio 2007; Meyer et al. 2009). Second, flower flies present a wide variety of larval functional groups (e.g. phytophagous, mycophagous, saprophagous, zoophagous) (Rotheray 1993) and most species require particular macro and microhabitats for breeding, which are not available in the agricultural matrix (Schweiger et al. 2007; Jauker et al. 2009; Meyer et al. 2009; Ricarte et al. 2011; Rotheray and Gilbert 2011).

\section{Responses of the dominant species}

The two most abundant types of non-crop habitats in the study region (abandoned pastures and Seasonal Semideciduous Forest) seem to complement adult and larval requirements for most flower fly species. Abandoned pastures support a high density and diversity of weeds (Medeiros et al. 2016) and provide (1) a steady supply of pollen and nectar for adult flies and (2) food mainly for phytophagous and zoophagous larvae (Rotheray and Gilbert 2011). Seasonal Semideciduous fragments are probably the main source of larvae microhabitats in the region, especially for the larvae that are not associated with specific vegetation structures (i.e. saprophagous breeding in aquatic media; Ricarte et al. 2011). Moreover, adult flower flies are probably dependent on floral resources available in the forest canopy (Sousa et al. 2014).

Similarly to non-crop habitats, arable fields are probably favorable habitats for the three dominant species. Despite the lack of information on the biology and ecology of Neotropical flower flies, A. exotica, P. clavatus and T. politus are well-known species whose forage in agricultural matrix. The first two are distributed from southern USA to South America and their larvae have been reported preying on many hemipteran pests (Rojo et al. 2003), 
Fig. 3 The best-supported models of the relationship between the percentage of non-crop habitats in 2-km buffers and species richness (a) and abundance (b) of flower flies in southern Brazil. Flower flies presented similar responses at all spatial scales. wAICc represents the evidence weight of the models
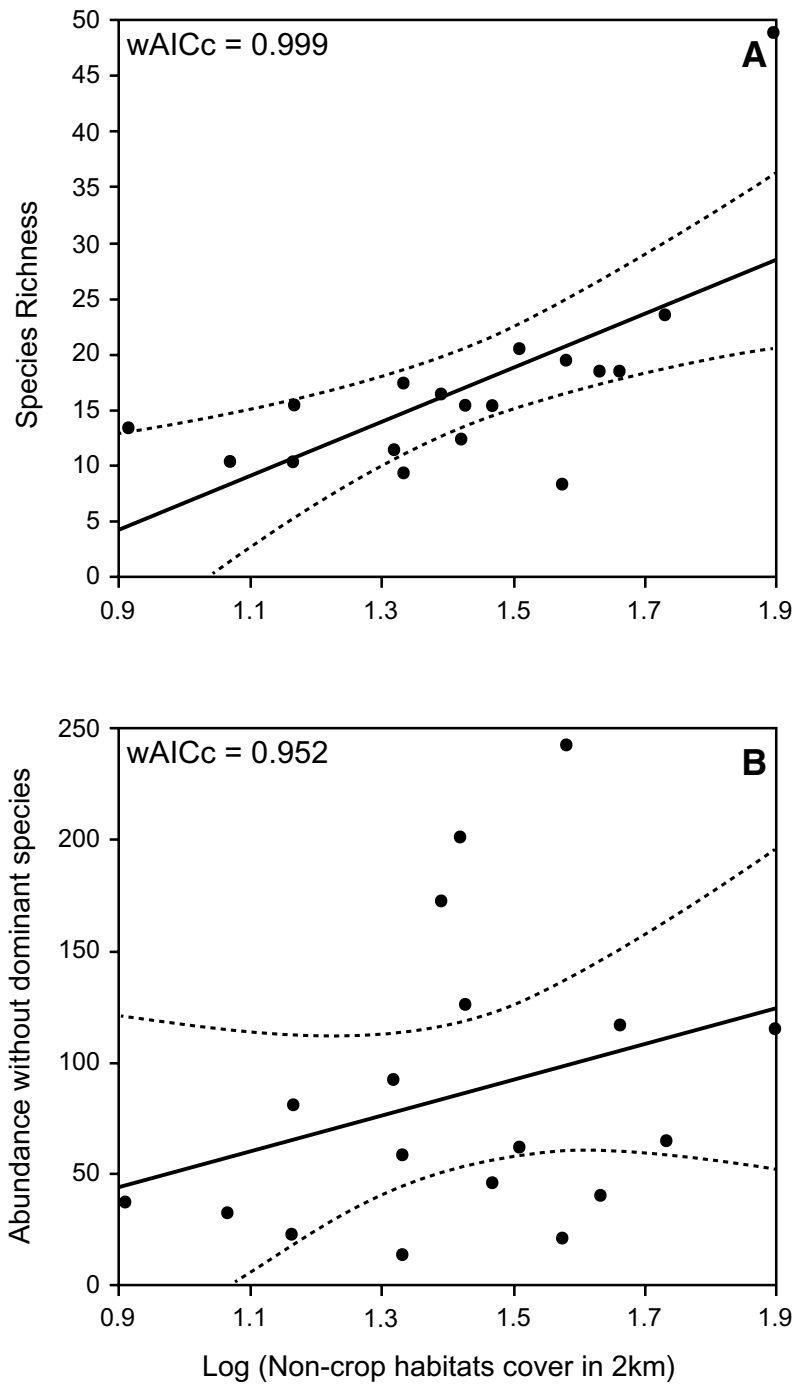

including pest aphids in cereal crops in southern Brazil (Gassen 1986; Bortolotto et al. 2016). There are records of $A$. exotica larvae preying on at least 20 species of aphids (Rojo et al. 2003; López et al. 2003; Resende et al. 2006; Smith and Chaney 2007; Manfrino et al. 2011; Sturza et al. 2011; Arcaya et al. 2017) and P. clavatus are able to prey on a similar number of aphids as well mainly tree aphids, in addition to grapevine phylloxera (Rojo et al. 2003). In addition, high numbers of $A$. exotica and $P$. clavatus in wheat crops located in crop-dominated landscapes occurs because of the spillover from neighbouring cereal crops where females search for aphid colonies for laying eggs. On the other hand, larvae of $T$. politus are pollenivorous and can feed on pollen of cultivated plants such as corn (Reemer and Rotheray 2009) and sorghum (Nunes-Silva et al. 2010). Thus, T. politus probably benefit from mass-flowering crops in the surrounding landscape, when both larval and adult stages. 
Table 2 Coefficients of determination $\left(\mathrm{R}^{2}\right)$ of the permutation test statistics of each explanatory variable and residuals of the RDA analysis for explain total beta diversity (Sorensen) and its components (Nested and Turnover) of flower flies within fragmented landscape of Atlantic Forest, Brazil

\begin{tabular}{llllllll}
\hline $\begin{array}{l}\text { Spatial } \\
\text { scales } \\
(\mathrm{km})\end{array}$ & Component & Altitude & Crop size & Pesticides & Non crop habitats & Edge density & Residuals \\
\hline 0.5 & & & & & & & \\
& Nested & 0.018 & 0.001 & 0.111 & $0.582^{* *}$ & 0.043 & 0.354 \\
& Turnover & 0.180 & 0.116 & 0.085 & 0.059 & 0.021 & 0.655 \\
& Sorensen & 0.078 & 0.040 & 0.030 & $0.285^{* *}$ & 0.011 & 0.544 \\
1.0 & Nested & 0.018 & 0.010 & 0.111 & 0.214 & 0.048 & 0.705 \\
& Turnover & 0.18 & 0.116 & 0.085 & 0.119 & 0.030 & 0.467 \\
& Sorensen & 0.078 & 0.040 & 0.030 & $0.190^{*}$ & 0.030 & 0.630 \\
1.5 & Nested & 0.018 & 0.010 & 0.111 & $0.523^{* *}$ & 0.012 & 0.433 \\
& Turnover & 0.180 & 0.116 & 0.085 & 0.003 & 0.063 & 0.557 \\
& Sorensen & 0.078 & 0.040 & 0.030 & $0.285^{* *}$ & 0.024 & 0.541 \\
& Nested & 0.018 & 0.010 & 0.111 & $0.618^{* *}$ & 0.035 & 0.315 \\
& Turnover & 0.180 & 0.116 & 0.085 & 0.066 & 0.043 & 0.640 \\
& Sorensen & 0.078 & 0.040 & 0.030 & $0.306^{* *}$ & 0.021 & 0.523 \\
\hline
\end{tabular}

Values presented per each spatial scale

$*$ indicates the level of significance

$* \mathrm{p}<0.05 ; * * \mathrm{p}<0.01 ; * * * \mathrm{p}<0.001$
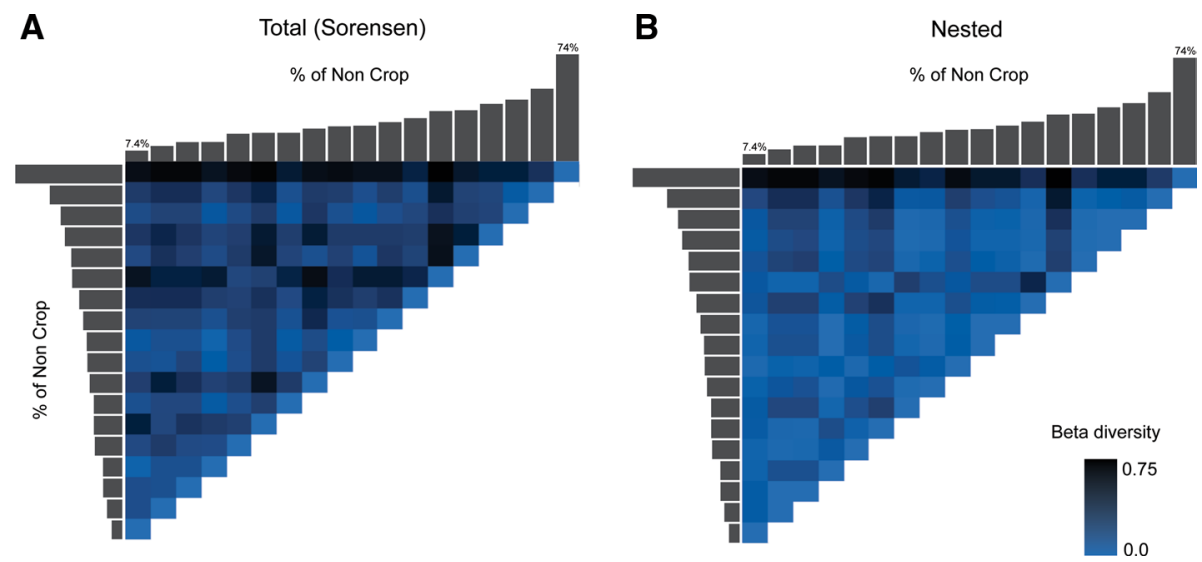

Fig. 4 Total beta diversity (a) and its nested component (b) between flower fly communities. Sites were sorted according the explanatory variable that best predicted the pattern of each type of beta diversity (percentage of non-crop land use at $2-\mathrm{km}$ scale for Sorensen index and the nested component)

As adult flower flies depend on floral resources and can disperse long distances (Holland and Thomas 1996) even crop-associated species, like the three dominant species, probably rely on adjacent non-crop habitats in periods of disturbance in arable fields. As an example, this may occur during harvest and pesticide application, as well as during periods of low resource availability (Tscharntke et al. 2007, 2012). Indeed, Bortolotto et al. (2016) found, in the same study region, that wheat crops under low levels of aphid infestation supported 
Fig. 5 Beta diversity components (nested a and turnover b) of flower fly communities plotted against the differences of percentage of non-crop habitats between pairs of landscapes. Line represents a linear regression with a Gaussian distribution
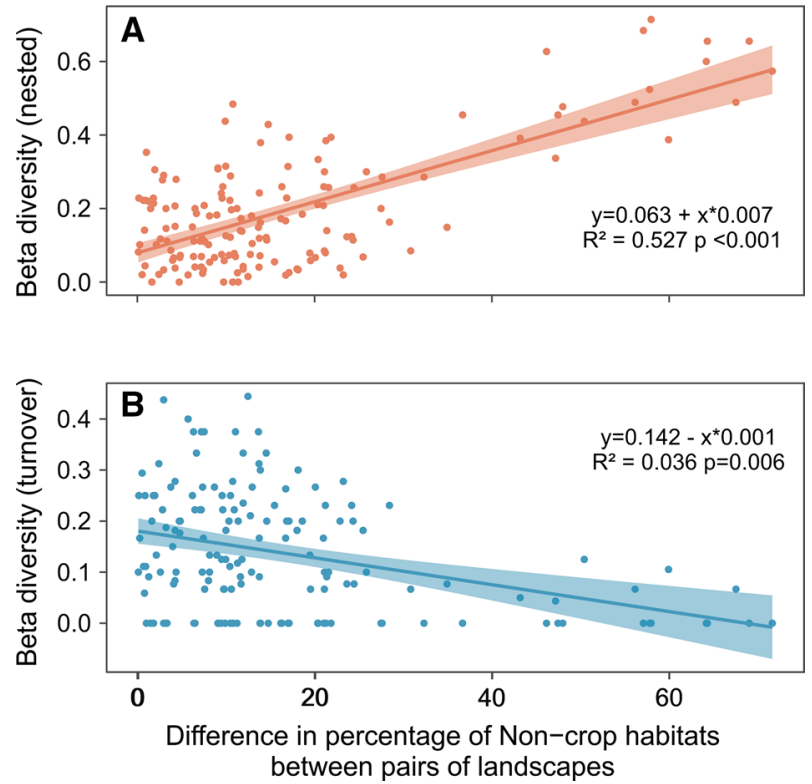

higher abundance of predatory flower flies at the edges near forest fragments than in the centre of the crops.

\section{Beta diversity responses}

Total beta diversity (Sorensen index) and its nested component were driven by percentage of non-crops habitats at multiple spatial scales. The nested beta diversity component indicates the loss of species between communities reflecting the consequences of selective extinction or loss of habitat resource (Ulrich et al. 2009). In the present study, habitat loss affected community composition in such way that communities located in crop dominated landscapes were composed of subsets of the communities located in landscapes with high percentage cover of non-crop habitats. The pairs of communities with larger differences in the percentage of non-crop habitats had high values of nested beta diversity, indicating an accentuated loss of flower fly species in landscapes with low percentage cover of non-crop habitats. Moreover, high levels of habitat loss probably disrupts the provision of ecosystem services provided by flower flies, once lost species are not replaced (low values of turnover).

Both nested and turnover components similarly influenced total beta diversity (Fig. 5), however the turnover component was not explained by our explanatory variables. Such absence of effect indicates that there are others factor such as phenological changes (Simanonok and Burkle 2014), crop management (Clough et al. 2007), water availability and local plant composition (Devoto et al. 2009) affecting this component of beta diversity.

\section{Flower flies conservation within agroecosystems}

Here, we provide the first insights into the importance of non-crop habitats for the conservation of flower flies within agroecosystems. Our findings suggest that non-crop habitats 
play a positive role in maintaining high flower fly richness and beta diversity in farmland. Non-crop habitats are permanent refuges for biodiversity against the constant anthropogenic disturbances in agricultural matrices, such as pesticide applications. These habitats probably enhance the long-term persistence of flower flies, reduce the risk of local extinction and possibly increase the provision of ecosystem services such as pollination and pest control in agroecosystems.

We also highlight that the positive association between flower flies and non-crop habitats was found at all spatial scales (from 0.5 to $2 \mathrm{~km}$ ). This indicates that most flower fly species present high dispersal capacity and strongly depend on the percentage of non-crop habitat at a landscape level to persist in farmland. Therefore, agri-environment schemes designed to preserve biodiversity in agricultural landscapes should promote the conservation and restoration of natural and semi-natural habitats. Furthermore, we suggest that conservation strategies should consider the landscape context prior to be defined. For instance, the effectiveness of local conservation management is highest in landscapes with intermediate complexity than in crop dominated landscapes or in complex landscapes (Batáry et al. 2011; Tscharntke et al. 2012). We recommend that in more complex landscapes — where biodiversity is high everywhere-conservation initiatives should focus on the maintenance of high proportions of noncrop habitats in order to guarantee high level of spillover of organisms between crop and noncrop habitats (Bianchi et al., 2006; Tscharntke et al. 2012). In agricultural landscapes with intermediate and low proportions of non-crop habitats we suggest combining habitat restoration at landscape scale (above $2 \mathrm{~km}$ ) with local conservation management initiatives such as organic systems (Krauss et al. 2011) and implantation of hedgerows and sown flower strips in the edges of arable fields (Haenke et al. 2009, 2014; Jönsson et al. 2015). Such combined initiatives can increase flower fly diversity and their ecosystem services within the agricultural matrix.

Although flower flies provide pollination and biological control services in agroecosystems, this group remains poorly studied in the Neotropical region, where little is known about their biology and functional ecology (Pérez-Bañón et al. 2003; Mengual et al. 2008; Amorim 2009). Thus, improving our knowledge on flower flies and other functional groups is not only important for conserving biodiversity, but also from a sustainable agriculture perspective. Future studies should focus on (i) describing flower fly larvae functional groups and their micro-habitat requirements and (ii) investigating how flower flies and other functionally important arthropod groups interact with natural and managed ecosystems at several spatial and temporal scales. Such information is essential in order to conserve and enhance biodiversity and ecosystem services in agricultural landscapes.

Acknowledgements We are grateful to the owners of private lands where the sampled wheat crops are located. We thank Luciane Marinoni for permission to study the Syrphidae collection of DZUP, Gil F. G. Miranda for helping with Ocyptamus sensu lato identifications and the two anonymous reviewers who helped us to substantially improve the manuscript. HRM and AHT received a research grant from the Brazilian Coordination for the Improvement of Higher Education Personnel (CAPES). MíNM was supported by CAPES (PNPD process 20131282). DWC was funded by the São Paulo Research Foundation (FAPESP_process 2014/01594-4). Brazilian Government Research Council (CNPq) provided a research Grant for MCR (312045/2013-1; 312292/2016-3), who also thanks the financial support by FAPESP (process 2013/50421-2). We thank Pavel Dodonov for the proofreading of the manuscript. 


\section{References}

Altieri MA (1999) The ecological role of biodiversity in agroecosystems. Agric Ecosyst Environ 74:19-31. https://doi.org/10.1016/b978-0-444-50019-9.50005-4

Amorim DS (2009) Neotropical Diptera diversity: richness, patterns, and perspectives. In: Pape T, Bickel D, Meier R (eds) Diptera diversity: status, challenges and tools. Koninklijke Brill, Leiden, pp 71-97. https://doi.org/10.1163/ej.9789004148970.i-459.17

Anderson MJ (2001) Permutational multivariate analysis of variance. Department of Statistics, University of Auckland, Auckland

Arcaya E, Pérez-Bañón C, Mengual X, Zubcoff-Vallejo JJ, Rojo S (2017) Life table and predation rates of the syrphid fly Allograpta exotica, a control agent of the cowpea aphid Aphis craccivora. Biol Control 115:74-84. https://doi.org/10.1016/j.biocontrol.2017.09.009

Aviron S, Burel F, Baudry J, Schermann N (2005) Carabid assemblages in agricultural landscapes: impacts of habitat features, landscape context at different spatial scales and farming intensity. Agric Ecosyst Environ 108:205-217

Baselga A (2010) Partitioning the turnover and nestedness components of beta diversity. Glob Ecol Biogeogr 19:134-143. https://doi.org/10.1111/j.1466-8238.2009.00490.x

Baselga A, Orme CDL (2012) Betapart: an R package for the study of beta diversity. Methods Ecol Evol 3:808-812. https://doi.org/10.1111/j.2041-210X.2012.00224.X

Batáry P, Báldi A, Kleijn D, Tscharntke T (2011) Landscape-moderated biodiversity effects of agri-environment management: a meta-analysis. Proc Soc Lond Ser B-Biol Sci 278:1894-1902. https://doi. org/10.1098/rspb.2010.1923

Bates D, Maechler M, Bolker B, Walker S (2015) Fitting linear mixed-effects models using lme4. J Stat Softw 67:1-48. https://doi.org/10.18637/jss.v067.i01

Bianchi FJJA, Booij CJH, Tscharntke T (2006) Sustainable pest regulation in agricultural landscapes: a review on landscape composition, biodiversity and natural pest control. Proc Royal Soc B: Biol Sci 273(1595): 1715-1727

Buhk C, Alt M, Steinbauer MJ, Beierkuhnlein C, Warren SD, Jentsc A (2017) Homogenizing and diversifying effects of intensive agricultural land-use on plant species beta diversity in Central Europe-A call to adapt our conservation measures. Sci Total Environ 576:225-233. https://doi.org/10.1016/j. scitotenv.2016.10.106

Billeter R, Liira J, Bailey D, Bugter R, Arens P, Augenstein I, Aviron S, Baudry J, Bukacek R, Burel F, Cerny M, De Blust G, De Cock R, Diekötter T, Dietz H, Dirksen J, Dormann C, Durka W, Frenzel M, Hamersky R, Hendrickx F, Herzog F, Klotz S, Koolstra B, Lausch A, Le Coeur D, Maelfait JP, Opdam P, Roubalova M, Schermann A, Schermann N, Schmid T, Schweiger O, Smulders MJM, Speelmans M, Simova P, Verboom J, van Wingerden WKRE, Zobel M (2008) Indicators for biodiversity in agricultural landscapes: a pan-European study. J Appl Ecol 45:141-150. https://doi. org/10.1111/j.1365-2664.2007.01393.x

Bolker BM (2010) bbmle: Tools for general maximum likelihood estimation. The Comprehensive R Archive Network (CRAN), Vienna, Austria

Borges ZM, Couri MS (2009) Revision of Toxomerus Macquart, 1855 (Diptera: Syrphidae) from Brazil with synonymic notes, identification key to the species and description of three new species. Zootaxa 2179:1-72

Borges ZM, Pamplona DM (2003) Revision of the Neotropical Xanthandrus Verral (Diptera, Syrphidae). Rev Bras Entomol 47:155-167. https://doi.org/10.1590/s0085-56262003000200002

Bortolotto OC, de Menezes AO Jr, Hoshino AT, Campos TA (2016) Distance from the edge of forest fragments influence the abundance of aphidophagous flower flies (Diptera: Syrphidae) in wheat fields. Acta Sci 38:157-164. https://doi.org/10.4025/actasciagron.v38i2.27711

Burgio G, Sommaggio D (2007) Syrphids as landscape indicators in Italian agroecosystems. Agric Ecosyst Environ 120:416-422. https://doi.org/10.1016/j.agee.2006.10.021

Burnham KP, Anderson DR (1998) Model Selection and Inference: a Practical Information-Theoretic Approach. Springer-Verlag, New York. https://doi.org/10.1007/978-1-4757-2917-7_3

Burnham KP, Anderson DR (2002) Model selection and multimodel inference: a practical information-theoretical approach, 2nd edn. Springer-Verlag, New York. https://doi.org/10.1007/b97636

Catano CP, Dickson TL, Myers JA (2017) Dispersal and neutral sampling mediate contingent effects of disturbance on plant beta-diversity: a meta-analysis. Ecol Lett 20(3):347-356. https://doi.org/10.1111/ ele. 12733

Clough Y, Holzschuh A, Gabriel D, Purtauf T, Kleijn D, Kruess A, Steffan-Dewenter I, Tscharntke T (2007) Alpha and beta diversity of arthropods and plants in organically and conventionally managed wheat fields. J Appl Ecol 44:804-812. https://doi.org/10.1111/j.1365-2664.2007.01294.x 
de Sousa JMT, Marinoni RC, Marinoni L (2014) Open and disturbed habitats support higher diversity of Syrphidae (Diptera)? A case study during three yr of sampling in a fragment of Araucaria forest in Southern Brazil. J Insect Sci 14:1-8. https://doi.org/10.1093/jisesa/ieu098

Devoto M, Medan D, Roig-Alsina A, Montaldo NH (2009) Patterns of species turnover in plant-pollinator communities along a precipitation gradient in Patagonia (Argentina). Aust Ecol 34:848-857. https:// doi.org/10.1111/j.1442-9993.2009.01987.x

ESRI (Environmental Systems Research Institute) (2005) ArcGIS Desktop: Release 8

Fahrig L (2003) Effects of habitat fragmentation on biodiversity. Annu Rev Ecol Evol Syst 34:487-515. https://doi.org/10.1146/annurev.ecolsys.34.011802.132419

Fahrig L (2017) Ecological responses to habitat fragmentation Per Se. Annu Rev Ecol Evol Syst 48(1):1-23

Fahrig L, Baudry J, Brotons L, Burel FG, Crist TO, Fuller RJ, Sirami C, Siriwardena GM, Martin JL (2011) Functional landscape heterogeneity and animal biodiversity in agricultural landscapes. Ecol Lett 14:101-112. https://doi.org/10.1111/j.1461-0248.2010.01559.x

FAO (1988) FAO/UNESCO Soil map of the world, revised legend with corrections and updates. World Soil Resources Report 60, FAO, Rome. Reprinted with updates as technical paper 20 (1997), ISRIC, Wageningen

Fontaine C, Dajoz I, Meriguet J, Loreau M (2006) Functional diversity of plant-pollinator Interaction webs enhances the persistence of plant communities. PLoS Biol 4:129-135. https://doi.org/10.1371/journal.pbio.0040001

Gassen DN (1986) Parasitos, patógenos e predadores de insetos associados à cultura do trigo. Embrapa trigo, Brazil

Geiger F, Bengtsson JF, Berendse F, Weisser WW, Emmerson M, Morales MB, Ceryngier P, Liira J, Tscharntke T, Winqvist C, Eggers S, Bommarco R, Pärt T, Bretagnolle V, Plantegenest M, Clement LW, Dennis C, Palmer C, Oñate JJ, Guerrero I, Hawro V, Aavik T, Thies C, Flohre A, Hänke S, Fischer C, Goedhart PW, Inchausti P (2010) Persistent negative effects of pesticides on biodiversity and biological control potential on European farmland. Basic Appl Ecol 11:97-105. https://doi. org/10.1016/j.baae.2009.12.001

Gilbert F, Rotheray GE, Zafar R, Emerson P (1994) The evolution of feeding strategies. In: Eggleton P, Vane-Wright R (eds) Phylogenetics and Ecology. Academic Press, London, pp 324-343

González E, Salvo A, Valladares G (2015) Sharing enemies: evidence of forest contribution to natural enemy communities in crops, at different spatial scales. Insect Conserv Diver 8:359-366. https://doi. org/10.1111/icad.12117

González E, Salvo A, Defagó MT, Valladares G (2016a) A moveable feast: insects moving at the forestcrop interface are affected by crop phenology and the amount of forest in the landscape. PLoS ONE 11:e0158836. https://doi.org/10.1371/journal.pone.0158836

González E, Salvo A, Valladares G (2016b) Natural vegetation cover in the landscape and edge effects: differential responses of insect orders in a fragmented forest. Insect Sci 24:891-901. https://doi. org/10.1111/1744-7917.12377

González E, Salvo A, Valladares G (2017) Arthropod communities and biological control in soybean fields: forest cover at landscape scale is more influential than forest proximity. Agric Ecosyst Environ 239:359-367. https://doi.org/10.1016/j.agee.2017.02.002

Grez AA, Prado E (2000) Effect of plant patch shape and surrounding vegetation on the dynamics of predatory coccinellids and their prey Brevicoryne brassicae (Hemiptera: Aphididae). Environ Entomol 29:1244-1250. https://doi.org/10.1603/0046-225x-29.6.1244

Haenke S, Scheid B, Schaefer M, Tscharntke T, Thies C (2009) Increasing syrphid fly diversity and density in sown flower strips within simple vs. complex landscapes. J Appl Ecol 46:1106-1114. https://doi. org/10.1111/j.1365-2664.2009.01685.x

Haenke S, Kovács-Hostyánszki A, Fründ J, Batáry P, Jauker B, Tscharntke T, Holzschuh A (2014) Landscape configuration of crops and hedgerows drives local syrphid fly abundance. J Appl Ecol 51:505513. https://doi.org/10.1111/1365-2664.12221

Hendrickx F, Maelfait JP, Wingerden WV, Schweiger O, Speelmans M, Aviron S, Augenstein I, Billeter R, Bailey D, Bukacek R, Burel F, Diekötter T, Dirksen J, Herzog F, Liira J, Roubalova M, Vandomme V, Rob Bugter R (2007) How landscape structure, land-use intensity and habitat diversity affect components of total arthropod diversity in agricultural landscapes. J Appl Ecol 44:340-351. https://doi. org/10.1111/j.1365-2664.2006.01270.x

Holland JM, Thomas SR (1996) Phacelia tanacetifolia flower strip: their effect on beneficial invertebrates and gamebird chick foo in an integrated farming system. Acta Jutl Nat Sci Ser 71:171-182

Holzschuh A, Steffan-Dewenter I, Tscharntke T (2010) How do landscape composition and configuration, organic farming and fallow strips affect the diversity of bees, wasps and their parasitoids? J Anim Ecol 79:491-500. https://doi.org/10.1111/j.1365-2656.2009.01642.x 
Hurvich CM, Tsai CL (1989) Regression and time series model selection in small samples. Biometrika 76:297-307

IAPAR (2000) Cartas climáticas do estado do Paraná. http://www.iapar.br/modules/conteudo/conteudo. php?conteudo=856. Accessed 27 Nov 2016

Jauker F, Wolters V (2008) Flower flies are efficient pollinators of oilseed rape. Oecologia 156:819-823. https://doi.org/10.2307/2336663

Jauker F, Diekötter T, Schwarzbach F, Wolters V (2009) Pollinator dispersal in an agricultural matrix: opposing responses of wild bees and flower flies to landscape structure and distance from main habitat. Landsc Ecol 24:547-555. https://doi.org/10.1007/s10980-009-9331-2

Jönsson AM, Ekroos J, Dänhardt J, Andersson GKS, Olsson O, Smith HG (2015) Sown flower strips in southern Sweden increase abundances of wild bees and hoverflies in the wider landscape. Biol Conserv 184:51-58. https://doi.org/10.1016/j.biocon.2014.12.027

Kleijn D, van Langevelde F (2006) Interacting effects of landscape context and habitat quality on flower visiting insects in agricultural landscapes. Basic Appl Ecol 7:214-301. https://doi.org/10.1016/j. baae.2005.07.011

Krauss J, Gallenberger I, Steffan-Dewenter I (2011) Decreased functional diversity and biological pest control in conventional compared to organic crop fields. PLoS ONE 6:e19502. https://doi. org/10.1371/journal.pone.0019502

Landis DA, Wratten SD, Gurr GM (2000) Habitat management to conserve natural enemies of arthropod pests in agriculture. Annu Rev Entomol 45:175-201. https://doi.org/10.1146/annurev. ento.45.1.175

Larrivée M, Fahrig L, Drapeau P (2008) Edge effects created by wildfire and clear-cutting on boreal forest ground-dwelling spiders. For Ecol Manage 255:1434-1445. https://doi.org/10.1016/j. foreco.2007.10.062

Legendre P, Legendre L (eds) (2012) Numerical ecology, vol 24. Elsevier, Oxford

López O, Salto C, Luiselli S (2003) Foeniculum vulgare Miller como hospedera de pulgones y sus enemigos naturales en otoño. Rev FAVE Cienc. Agrar 2:55-65

Loreau M, Mouquet N, Gonzalez A (2003) Biodiversity as spatial insurance in heterogeneous landscapes. Proc Natl Acad Sci USA 100:12765-12770. https://doi.org/10.1073/pnas.2235465100

Lucas A, Bull JC, de Vere N, Neyland PJ, Forman DW (2017) Flower resource and land management drives hoverfly communities and bee abundance in seminatural and agricultural grasslands. Ecol Evol 7:8073-8086. https://doi.org/10.1002/ece3.3303

Magurran AE (2004) Measuring biological diversity. Blackwell, Maldan

Manfrino R, Salto C, Zumoffen L (2011) Estudio de las asociaciones áfidos entomófagos sobre Foeniculum vulgare (Umbelliferae) y Conyza bonariensis (Asteraceae) en la región central de Santa Fe, Argentina. Rev Soc Entomol Argent 70:99-109

Martensen AC, Pimentel RG, Metzger JP (2008) Relative effects of fragment size and connectivity on bird community in the Atlantic Rain Forest: implications for conservation. Biol Conserv 141:2184-2192. https://doi.org/10.1016/j.biocon.2008.06.008

Martensen AC, Ribeiro MC, Banks-Leite C, Prado PI, Metzger JP (2012) Associations of forest cover, fragment area, and connectivity with Neotropical understory bird species richness and abundance. Conserv Biol 26:1100-1111. https://doi.org/10.1111/j.1523-1739.2012.01940.x

McGarigal K (2015) Fragstats help. http://www.umass.edu/landeco/research/fragstats/documents/fragstats_documents.html. Accessed 28 March 2017

Medeiros HR, Hoshino AT, Ribeiro MC, Menezes Junior AO (2016) Landscape complexity affects cover and species richness of weeds in Brazilian agricultural environments. Basic Appl Ecol 17:731740. https://doi.org/10.1016/j.baae.2016.10.001

Meehan TD, Werling BP, Landis DA, Gratton C (2011) Agricultural landscape simplification and insecticide use in the Midwestern United States. Proc Natl Acad Sci USA 108:11500-11505. https:// doi.org/10.1073/pnas.1100751108

Mengual X (2011) Black-tie dress code: two new species of the genus Toxomerus (Diptera, Syrphidae). ZooKeys 140:1-26. https://doi.org/10.3897/zookeys.140.1930

Mengual X, Ståhls G, Rojo S (2008) First phylogeny of predatory flower flies (Diptera, Syrphidae, Syrphinae) using mitochondrial COI and nuclear 28S rRNA genes: conflict and congruence with the current tribal classification. Cladistics 24:543-562. https://doi.org/10.1111/j.1096-0031.2008.00200.x

Mengual X, Ruiz C, Rojo S, Ståhls G, Thompson FC (2009) A conspectus of the flower fly genus Allograpta (Diptera: Syrphidae) with description of a new subgenus and species. Zootaxa 2214:1-28

Meyer B, Jauker F, Steffan-Dewenter I (2009) Contrasting resource-dependent responses of flower fly richness and density to landscape structure. Basic Appl Ecol 10:178-186. https://doi. org/10.1016/j.baae.2008.01.001 
Miranda GFG (2017) Revision of the Hybobathus arx and Pelecinobaccha summa species groups (Diptera: Syrphidae). Zootaxa 4338:1-43. https://doi.org/10.11646/zootaxa.4338.1.1

Miranda GFG, Marshall SA, Skevington JH (2014) Revision of the genus Pelecinobaccha Shannon, description of Relictanum gen. nov., and redescription of Atylobaccha flukiella (Curran, 1941) (Diptera: Syrphidae). Zootaxa 3819:1-154. https://doi.org/10.11646/zootaxa.3819.1.1

Gardiner MM, Landis DA, Gratton C, DiFonzo CD, O’Neal M, Chacon JM, Wayo MT, Schmidt NP, Mueller EE, Heimpel GE (2009) Landscape diversity enhances biological control of an introduced crop pest in the north-central USA. Ecol Appl 19:143-154. https://doi.org/10.1890/07-1265.1

Mueller AL, Dauber J (2016) Hoverflies (Diptera: Syrphidae) benefit from a cultivation of the bioenergy crop Silphium perfoliatum L. (Asteraceae) depending on larval feeding type, landscape composition and crop management. Agric For Entomol 18:419-431. https://doi.org/10.1111/afe.12175

Nunes-Silva P, Cordeiro GD, Obregon D, Lima-Neto JF, Thompson FC, Viana BF, Freitas BM, Kevan PG (2010) Pollenivory in larval and adult flower flies: pollen availability and visitation rate by Toxomerus politus Say (Diptera: Syrphidae) on sorghum Sorghum bicolor (L.) Moench (Poaceae). Studia Dipt 17:177-185

Oksanen J, Kindt R, Legendre P, O’Hara B, Stevens MHH (2007) The vegan package. Community ecology package. 10:631-637

Pérez-Bañón C, Rotheray G, Hancock G, Marcos-García MA, Zumbado MA (2003) Immature stages and breeding sites of some Neotropical saprophagous syrphids (Diptera: Syrphidae). Ann Entomol Soc Am 96:458-471. https://doi.org/10.1603/0013-8746(2003)096[0458:isabso]2.0.co;2

Pinheiro J, Bates D, DebRoy S, Sarkar D, R Core Team (2017) nlme: Linear and nonlinear mixed effects models. R package version 3.1-131, http://CRAN.R-project.org/package=nlme

Reemer M, Rotheray GE (2009) Pollen feeding larvae in the presumed predatory syrphine genus Toxomerus Macquart (Diptera, Syrphidae). J Nat Hist 43:939-949. https://doi.org/10.1080/00222930802610576

Resende A, Silva E, Silva V, Ribeiro R, Guerra J, Aguiar-Menezes E (2006) First record of Lipaphis pseudobrassicae Davis (Hemiptera: Aphididae) and its association with predator insects, parasitoids and ants in kale (Cruciferae) in Brazil. Neotrop Entomol 35:551-555. https://doi.org/10.1590/ S1519-566X2006000400019

Ribeiro MC, Metzger JP, Martensen AC, Ponzoni FJ, Hirota MM (2009) The Brazilian Atlantic forest: how much is left, and how is the remaining forest distributed? Implications for conservation. Biol Conserv 142:1141-1153. https://doi.org/10.1016/j.biocon.2009.02.021

Ricarte A, Marcos-García MA, Moreno CE (2011) Assessing the effects of vegetation type on hoverfly (Diptera: Syrphidae) diversity in a Mediterranean landscape: implications for conservation. J Insect Conserv 15:865-877. https://doi.org/10.1007/s10841-011-9384-9

Rojo S, Gilbert F, Marcos-García MA, Nieto JM, Mier MP (2003) A world review of predatory flower flies (Diptera, Syrphidae: Syrphinae) and their prey. Cibio ediciones, Alicante

Rossetti MR, González E, Salvo A, Valladares G (2014) Not all in the same boat: trends and mechanisms in herbivory responses to forest fragmentation differ among insect guilds. Arthropod-Plant Interact 8:593-603. https://doi.org/10.1007/s11829-014-9342-z

Rotheray GE (1993) Colour guide to flower fly larvae (Diptera: Syrphidae). Whiteley, Sheffiled

Rotheray G, Gilbert F (2011) The natural history of flower flies. Forrest Text, Ceredigion

Schweiger O, Musche M, Bailey D, Billeter R, Diekötter T, Hendrickx F, Herzog F, Liira J, Maelfait JP, Speelmans M, Dziock F (2007) Functional richness of local hoverfly communities (Diptera, Syrphidae) in response to land use across temperate Europe. Oikos 116:461-472. https://doi. org/10.1111/j.2007.0030-1299.15372.x

Si X, Baselga A, Ding P (2015) Revealing beta-diversity patterns of breeding bird and lizard communities on inundated land-bridge islands by separating the turnover and nestedness components. PLoS ONE 10(5):e0127692. https://doi.org/10.1371/journal.pone.0127692

Simanonok MP, Burkle LA (2014) Partitioning interaction turnover among alpine pollination networks: spatial, temporal, and environmental patterns. Ecosphere 5:1-17. https://doi.org/10.1890/es14-00323.1

Smith H, Chaney W (2007) A survey of syrphid predators of Nasonovia ribisnigri in organic lettuce on the central coast of California. J Econ Entomol 100:39-48. https://doi.org/10.1093/jee/100.1.39

Sommaggio D (1999) Syrphidae: can they be used as environmental bioindicators? Agric Ecosyst Environ 74:343-356. https://doi.org/10.1016/s0167-8809(99)00042-0

Stapel JO, Cortesero AM, Lewis WJ (2000) Disruptive sublethal effects of insecticides on biological control: altered foraging ability and life span of a parasitoid after feeding on extrafloral nectar of cotton treated with systemic insecticides. Biol Control 17:243-249. https://doi.org/10.1006/bcon.1999.0795

Steffan-Dewenter I, Münzenberg U, Bürger C, Thies C, Tscharntke T (2002) Scale-dependent effects of landscape context on three pollinator guilds. Ecology 83:1421-1432. https://doi. org/10.1890/0012-9658(2002)083[1421:SDEOLC]2.0.CO;2 
Sturza V, Dorfey C, Poncio S, Dequech S, Bolzan A (2011) First record of larvae of Allograpta exotica (Wiedemann) (Diptera, Syrphidae) preying on Aphis gossypii Glover (Hemiptera, Aphididae) in watermelon in Brazil. Rev Bras Entomol 55:272-274. https://doi.org/10.1590/ S0085-56262011005000015

Thies C, Steffan-Dewenter I, Tscharntke T (2003) Effects of landscape context on herbivory and parasitism at different spatial scales. Oikos 101:18-25. https://doi.org/10.1034/j.1600-0706.2003.12567.x

Thompson FC (1999) A key to the genera the flower flies (Diptera: Syrphidae) of the Neotropical region including descriptions of new genera and species and a glossary of taxonomic terms. Contr Entomol Int 3:319-378

Thompson FC, Thompson BJ, Fairman JE (2000) Only in Costa Rica: new neotropical flower flies (Diptera: Syrphidae). Studia Dipt 7:33-43

Townes HA (1972) A light-weight Malaise trap. Entomol News 83:239-247

Tscharntke T, Klein AM, Kruess A, Steffan-Dewenter I, Thies C (2005) Landscape perspectives on agricultural intensification and biodiversity-ecosystem service management. Ecol Lett 8:857-874. https:// doi.org/10.1111/j.1461-0248.2005.00782.x

Tscharntke T, Bommarco R, Clough Y, Crist TO, Kleijn D, Rand TA, Tylianakis JM, van Nouhuys S, Vidal S (2007) Conservation biological control and enemy diversity on a landscape scale. Biol Control 43:294-309. https://doi.org/10.1016/j.biocontrol.2007.08.006

Tscharntke T, Tylianakis JM, Rand TA, Didham RK, Fahrig L, Batáry P, Bengtsson J, Clough Y, Crist TO, Dormann CF, Ewers RW, Fründ J, Holt RD, Holzschuh A, Klein AM, Kleijn D, Kremen C, Landis DA, Laurance W, Lindenmayer D, Scherber C, Sodhi N, Steffan-Dewenter I, Thies C, Van Der Putten WH, Westphal C (2012) Landscape moderation of biodiversity patterns and processes-eight hypotheses. Biol Rev 87:661-685. https://doi.org/10.1111/j.1469-185X.2011.00216.x

Ulrich W, Almeida-Neto M, Gotelli NJ (2009) A consumer's guide to nestedness analysis. Oikos 118:3-17. https://doi.org/10.1111/j.1600-0706.2008.17053.x

Whittaker RH (1965) Dominance and diversity in land plant communities. Science 147:250-260. https:// doi.org/10.1126/science.147.3655.250

Yachi S, Loreau M (1999) Biodiversity and ecosystem functioning in a fluctuating environment: the insurance hypothesis. Proc Natl Acad Sci USA 96:1463-1468. https://doi.org/10.1073/pnas.96.4.1463

Zaviezo T, Grez AA, Estades CF, Perez A (2006) Effects of habitat loss, habitat fragmentation, and isolation on the density, species richness, and distribution of ladybeetles in manipulated alfalfa landscapes. Ecol Entomol 31:646-656. https://doi.org/10.1111/j.1365-2311.2006.00830.x

Zellweger F, Roth T, Bugmann H, Bollmann K (2017) Beta diversity of plants, birds and butterflies is closely associated with climate and habitat structure. Glob Ecol Biogeogr 26(8):898-906. https://doi. org/10.1111/geb.12598 